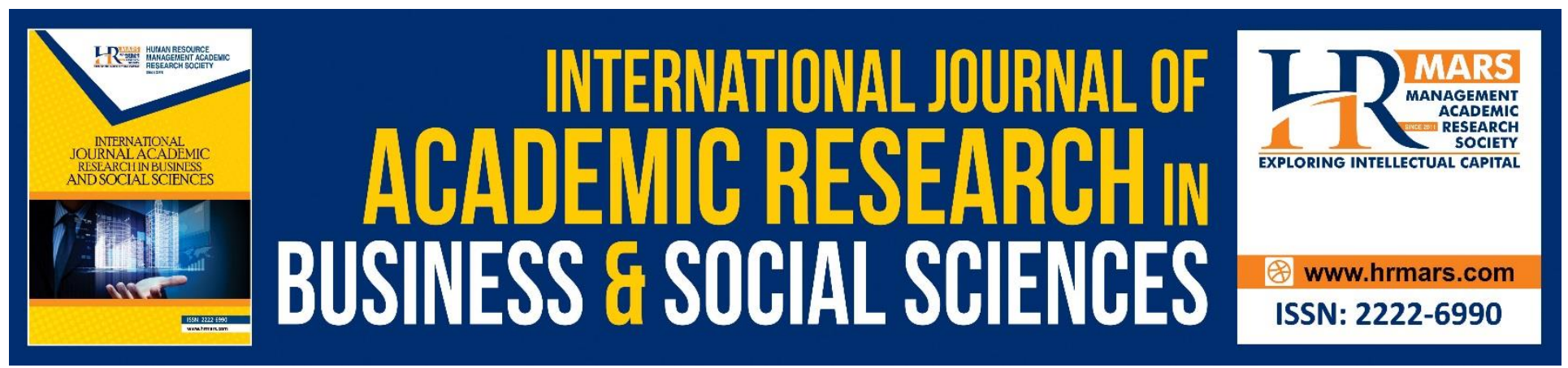

\title{
Do Work Ethics Improves Employee Job Satisfaction? Insights from Jordanian Banks
}

\author{
Hatem Mahmoud Al-Nashash, Shrikant Krupasindhu Panigrahi, \\ Mohd Ridzuan Bin Darun
}

To Link this Article: http://dx.doi.org/10.6007/IJARBSS/v8-i11/4708

DOI: $10.6007 /$ IJARBSS/v8-i11/4708

Received: 16 Sept 2018, Revised: 21 Oct 2018, Accepted: 17 Nov 2018

Published Online: 21 Nov 2018

In-Text Citation: (Al-Nashash, Panigrahi, \& Darun, 2018)

To Cite this Article: Al-Nashash, H. M., Panigrahi, S. K., \& Darun, M. R. Bin. (2018). Do Work Ethics Improves Employee Job Satisfaction? Insights from Jordanian Banks. International Journal of Academic Research in Business and Social Sciences, 8(11), 627-645.

\section{Copyright: @ 2018 The Author(s)}

Published by Human Resource Management Academic Research Society (www.hrmars.com)

This article is published under the Creative Commons Attribution (CC BY 4.0) license. Anyone may reproduce, distribute, translate and create derivative works of this article (for both commercial and non-commercial purposes), subject to full attribution to the original publication and authors. The full terms of this license may be seen

at: http://creativecommons.org/licences/by/4.0/legalcode

\section{Vol. 8, No. 11, 2018, Pg. 627 - 645}

Full Terms \& Conditions of access and use can be found at http://hrmars.com/index.php/pages/detail/publication-ethics 


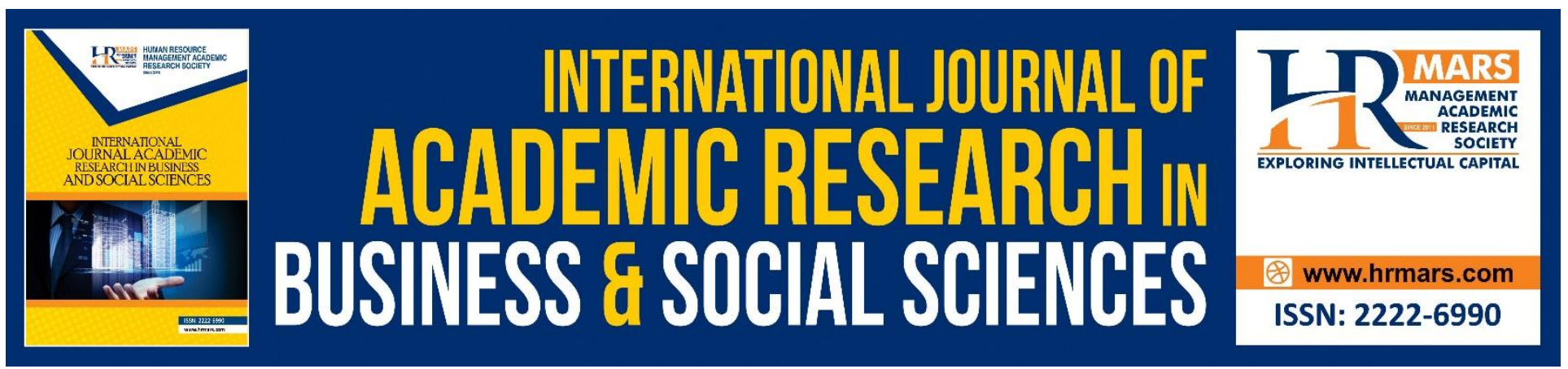

\title{
Do Work Ethics Improves Employee Job Satisfaction? Insights from Jordanian Banks
}

\author{
Hatem Mahmoud Al-Nashash \\ Ph.D. Student, Faculty of Industrial Management, University Malaysia Pahang, \\ Kuantan, Malaysia \\ Email: temo.nasho@yahoo.com \\ Shrikant Krupasindhu Panigrahi \\ Senior Lecturer, Faculty of Industrial Management, University Malaysia Pahang, \\ Kuantan, Malaysia \\ Email: pshrikant@ump.edu.my \\ Mohd Ridzuan Bin Darun \\ Associate Professor, Faculty of Industrial Management, University Malaysia Pahang, \\ Kuantan, Malaysia \\ Email: mridzuand@ump.edu.my
}

\begin{abstract}
Ethics is a very crucial to understand how well an employee is doing. Ethics of work shows how much an employee value them. Thus, this study examines the impact of strong work ethics on job satisfaction among banking employees in Jordan. There has been growing evidence supporting the association between work ethics and job satisfaction of employees. However, it is not clear why such association exists. This paper argues that in order to provide a clear understanding and convincing explanation of this association there is a need to improve the theoretical and analytical framework. Quantitative method with survey questionnaire was administered to collect information on work ethics and job satisfaction from 89 employees working in Jordanian banks. The finding of the study revealed that work ethics are positively associated with job satisfaction. These findings imply that work ethics is one of the key attributes to increase employee's job satisfaction together with other organizational outcomes. Most importantly, it is crucial for the managers to be aware that increasing employee's job satisfaction can lead to increased organizational commitment, lower labor turnover and improve productivity.
\end{abstract}

Keywords: Work ethics, job satisfaction, Jordanian banks 


\section{Introduction}

One of the most important activities in human life all day is work. In the field of human resource, work ethics has gained focus of research to promote ethical behavior in the workplace (Khan and Rasheed, 2015). Others who consider the work as a source of income for improving the standard of living, add property wealth, recognize or appreciation and self-glory. Strong work ethics in the organization is the key to the ethical behavior of employees. Organizations that focus on developing strong work ethics relevant to the issues faced by employees will lead to the employees behaving ethically (Valentine \& Barnett, 2007b). Beyond salary, strong work ethics is able to influence human beings to commit or not to commit a crime. Empowerment within the organization remains weak due to lack of work ethics that are no longer able to enhance job satisfaction of employees (Steinheider, 2006). Managers in the working environment are messed with the ethical confrontation with others (Murtaza et al., 2016b). This ethical dilemma makes them exposed to their own engaged and integrated activities including fraudulent acts. The honesty of managers become limited are unable them to diverse the job filled with vagueness (Sun, Gergen, Avila, \& Green, 2016).

For managers, it is difficult to get escaped from such ethical dilemmas and the morals of the managers are always questionable in order to understand their behaviors with others. Ethical dilemmas like the events of corruption charges, reject to work honestly and other possible scandals are some of the critical subjects that need to investigate in order to understand work ethics (Forte \& Hansvick, 1999). Moreover, it is sometimes hard for the employees or managers to get escaped with such ethical dilemmas, but if the individual is exposed to ethical interactions and enrichments the behavior can change positively resulting to positive job satisfaction.

Furthermore, (Camp, 1994; Getahun, Sims, \& Hummer, 2008) found that one of the negative consequences associated with low levels of job satisfaction includes lack of active participation in decision making and often faces ethical issues stemming from employee behavior. Thus it is important to consider employee working conditions and the managers must be aware of the safety of their employees in order to compensate them when they perform the unusual or difficult task. The unethical working condition leads to stress when there is no cooperation between job needs and competencies.

With the vision of what motivates operatives, managers can larger ascertain what makes the employees do their best job. There is a need for the managers to understand what propels their subordinates and colleagues in order to be competent heads in the work place. The recommendations in this study will enable managers to become the best presentation out of their operatives and rise productivity in their departments.

\section{Literature Review}

When an organization employs the individuals they bring work into not unique job skills but also his or her ethics. In today's business work ethics is very important due to changes in employee behaviors that play a crucial role in the success of the organization. According to Valentine and Barnett (2007a) the crime committed by an employee results in the deterioration of corporate image drastically. In any empirical research, there is a need for a clear view of independent constructs. Theoretical aspects help us to provide clear views on our independent variables. Currently, there is a confusion on the selection of dimensions of work ethics. 
INTERNATIONAL JOURNAL OF ACADEMIC RESEARCH IN BUSINESS AND SOCIAL SCIENCES

Vol. 8, No. 11, Nov, 2018, E-ISSN: 2222-6990 @ 2018 HRMARS

\section{Theoretical view on Job Satisfaction}

There are many approaches and theories about satisfaction. However, we have a specific theory related to explain job satisfaction often built on disciplinary perspectives like psychology and performance. It is not an easy task to confirm the theories. In the field of behavioral research, measurement of satisfaction is often described as the key issue. We, therefore, might be tempted to extend this to the study of employee job satisfaction.

Neither the descriptive nor the strategic model are able to provide much insight into how work ethics translates into satisfaction. They sensibly view ethics as the only part of the explanation for performance and suggests various sub system that aligns and support each other for superior performance. The right people will be in right place to do right things.

In the strategic version, the descriptive models give more weightage to the active role of employees due to their employee relation roots. In contract, more specific behavioral theories focus on the organizational psychology with an assumption that ethics increases motivation and commitment of employees. The key factors that constitute satisfaction are derived from specific theories of motivation, expectation and goal setting and so on. The key features of this theories spell out the linkage between work ethics and job satisfaction.

Starting with the latter in a broader level, the expectancy theory of motivation provides a coherent rationale for the linkage between ethics and satisfaction. This approach in relation to ethics and satisfaction was adopted by (Alsop \& Heinsohn, 2005; Apasu, 1986) who suggested that,

"Unethical employees operating in an ethical organization should experience a misfit and be more willing to leave the organization. When employees possess knowledge and skills that are absent in the manager, employees are motivated to apply those skills and knowledge in discretionary efforts".

The expectancy theory to Victor, (1964), explains that "job satisfaction on the basis that the procedure of satisfaction or dissatisfaction transpires as a consequence of the analogy". Consequently, the theory basically describes an individual's understanding of the connection between efforts needed the level of anticipated presentation and the anticipated level of rewards.

Maslow promulgated with motivation and personality which presented his theory on the satisfaction of people through their personal requirements about how people satisfy various personal needs. It is often clear in many cases as a pyramid with the survival need at the broad-based bottom and the necessity of self-realization at the narrow top (Gawel, 1997). Maslow's (1970) hierarchy of needs theory in which needs have been identified in the form of a hierarchical gradient is a five-level. The least request comprised of the fundamental physiological needs, for example, water, sustenance, and shelter. The second request comprised of physical and money related security. The third request comprised of social needs which included having a place, affection, and acknowledgement of others. The fourth request comprised of self-regard and acknowledgment by companions. The fifth and most elevated request of necessities comprised of self-completion; which included self-advancement, independence, and self-bearing. On the premise of Maslow's hypothesis, work fulfillment has been drawn closer by a few analysts from the point of view of need satisfaction (Gui, Barriball, \& While, 2009). 
INTERNATIONAL JOURNAL OF ACADEMIC RESEARCH IN BUSINESS AND SOCIAL SCIENCES Vol. 8, No. 11, Nov, 2018, E-ISSN: 2222-6990 @ 2018 HRMARS

\section{Empirical evidence on work ethics and job satisfaction}

Previous research has shown that ethics is a humanistic device to improve the quality of working life for police personnel (Lincoln, Travers, Ackers, \& Wilkinson, 2002). In addition, it enhances the ability of an individual or group to make options and transfer those options to the required procedures and results (Alsop \& Heinsohn, 2005). Indeed, a management pattern which leads to employee motivation is the antithesis of an authoritarian management style, where supervisors make all key decisions (Gill, Flaschner, \& Bhutani, 2010). Hence, employee motivation and participation flows from the general principle of participative management. Its aim is to achieve a positive link between participation of employees, Job Satisfaction, motivation and performance, personal commitment (Doughty \& Rinehart, 2004). In this regard, when they enjoy both the participation of employees and leader support, they regularly achieve their goals, either by improving Job Satisfaction or by successfully introducing a quality-enhancing innovation; addition improving employee's morale and Job Satisfaction (Doughty \& Rinehart, 2004; Vacharakiat, 2008). Previous research has shown that employee behavior is a form of freedom in which police personnel makes decisions to ensure maximum Job Satisfaction (Hunjra, UI Haq, Akbar, \& Yousaf, 2011). So, if certain guidelines are followed and its limitations are understood, Empowerment can be an effective tool (Nykodym, Simonetti, Nielsen, \& Welling, 1994).

Numerous studies have been conducted on the influence of work ethics on job satisfaction and found a positive relationship between them (Ali \& Al-Kazemi, 2007; Hussein et al., 2010; Okpara \& Wynn, 2008). While other researchers found weak or no significant influence of work ethics on job satisfaction (Elkins, 2007; Komari \& Djafar, 2013). Thus it becomes crucial to investigate the influence of work ethics on job satisfaction of employees.

\section{Table 1. Previous studies on ethics}

\begin{tabular}{|c|c|}
\hline Authors & $\begin{array}{l}\text { Relationship } \\
\text { ethics and }\end{array}$ \\
\hline $\begin{array}{l}\text { (Hamilton-Attwell, 1998; Turnipseed, 2002); (Koonmee, Singhapakdi, } \\
\text { Virakul, \& Lee, 2010) }\end{array}$ & Productivity \\
\hline $\begin{array}{l}\text { (Miller, Woehr, \& Hudspeth, 2002); (Furnham, 1982); (Petty \& Hill, } \\
\text { 2017); (Abdi, Nor, \& Radzi, 2014) }\end{array}$ & $\begin{array}{l}\text { Organizational } \\
\text { performance }\end{array}$ \\
\hline (Vitell \& Davis, 1990); (Kowal \& Roztocki, 2015); (Mahembe \& & Job Satisfaction \\
\hline (Thau, Derfler-Rozin, Pitesa, Mitchell, \& Pillutla, 2015); (Fu, 2014) & Behavior \\
\hline (Murtaza et al., 2016a); (Abdi et al., 2014) & $\begin{array}{l}\text { Organizational } \\
\text { commitment }\end{array}$ \\
\hline
\end{tabular}

Source: Prepared by the authors

There have been many studies investigated on the relationship between ethics and job satisfaction, however, the studies investigating the impact of work ethics on job satisfaction are limited. Research relating to ethics and organizational performance (Miller et al., 2002); (Furnham, 1982); (Petty \& Hill, 2017); (Abdi et al., 2014) productivity (Hamilton-Attwell, 1998; Turnipseed, 
2002); (Koonmee et al., 2010), job satisfaction (Vitell \& Davis, 1990); (Kowal \& Roztocki, 2015); (Mahembe \& Chipunza, 2014), behavior (Thau et al., 2015); (Fu, 2014), organizational commitment (Murtaza et al., 2016a); (Abdi et al., 2014) were found to have significant positive relationships. A critical review of these studies finds that while the relationship between ethics and productivity, organizational performance and job satisfaction behavior have been investigated in the individual settings, the relationship between work ethics and job satisfaction together have not discussed critically. Thus the present study examines the relationship between work ethics and job satisfaction among banking employees.

\section{Work ethics enhancing job satisfaction for research oriented work}

The primary objective of ethics enhancing job satisfaction is to create appropriate conditions for researchers who need the motivation to get engaged in research oriented work. Work ethics is a collection of values and morality that is used to describe the action and behavior of people and compare them by their culture (Geren, 2011). There are several components of work ethics discussed and highlighted by previous studies. This study focuses on components of work ethics like care, ethics code, regulations, instrumental, independence, hard work, and work as goal and time utilization. Measuring the concept of work ethics, in reality, is a multi-dimensional concept that focuses on work environment, focuses on a variety of subjects from leisure, and morality.

Care is defined as the attitude of the employees towards their colleagues and other people inside and outside the organization. When the employees get additional benefits and compensation from the company, they care for the company too by obeying professional codes ethically.

The ethics code is defined as the ethical code based on the professions of the individual employee. For the ethical behavior of the employees work ethics play an important role in the organization. Work ethics of the employee helps the organization to understand the behavior of the employee ethically (Valentine \& Barnett, 2007a). Code of ethics have been considered by Elçi and Alpkan (2009) that confirmed work attitude and job satisfaction.

Rules set for the employees to obey visualizing their attitude is considered as regulations. Increase in ethical behavior of employees encourages work regulation in the organization (Kaptein, 2008). Thus it is very important for the organization to control the work behavior of employees that will eventually improve their loyalty and satisfaction. Organizations that focus on pay and employee participation increases the commitment of the employees to the organizations.

Instrumental is defined as selflessness among employees towards their colleagues in the organization. Victor and Cullen (1988) investigated on the factors of work ethics like caring, instrumentality, regulation and found that work ethics helps to prevent issues that will be effective to the organization and employees. In the recent research performed by Shacklock, Manning, and Hort (2011) approach to the development and measurement of instrumental ethics lead to work 
satisfaction. They also defined instrumental as the degree to which employee look out their own interest.

The degree to which employees are guided by their moral beliefs personally is considered as independence (Shacklock et al., 2011). Employees have the right to be guided by their own interests in the organization. Each employee in the organization confirms what is right and wrong. The dimensions associated with independence with the principal of ethics are related to the employee's personal and moral beliefs. Employees focus on themselves and are guided by their own personal ethics.

Employees that have the attitude to work hard in the organization is defined as hard work. Faithful involvement and commitment to work lead to decrease unethical behavior like begging, laziness, and a waste of time. Quality of work was found to be more important than hard work with an integral component of motivation and human life. Based on these ideas, the following hypotheses are presented:

H1: Work ethics (Care, Ethics code, Regulations, instrumental, independence, hard work, and work as a goal) of the individual banking employees has significant effect on job satisfaction.

The behavior and the decision making of the employees have been influenced in the work environment; operationalization of the field of psychology includes distinguishing proof of the set of highlights of the social environment. Koh and El'Fred (2001) investigated the relationship between work values and organization's responsibility taking into account a specimen of employees in Singapore and found that inherent work qualities relate more similar to organizational responsibility than extrinsic work values.

While most of the empirical studies have focused on the role of work values, involvement, motivation, attitude on ethical behavior, an important area of research is to examine the consequences when work ethics of individuals are perceived to improve their job satisfaction. Managers can favorably influence organizational outcomes by supporting and rewarding ethics of individual employees (Koh and Elfred, 2001). 


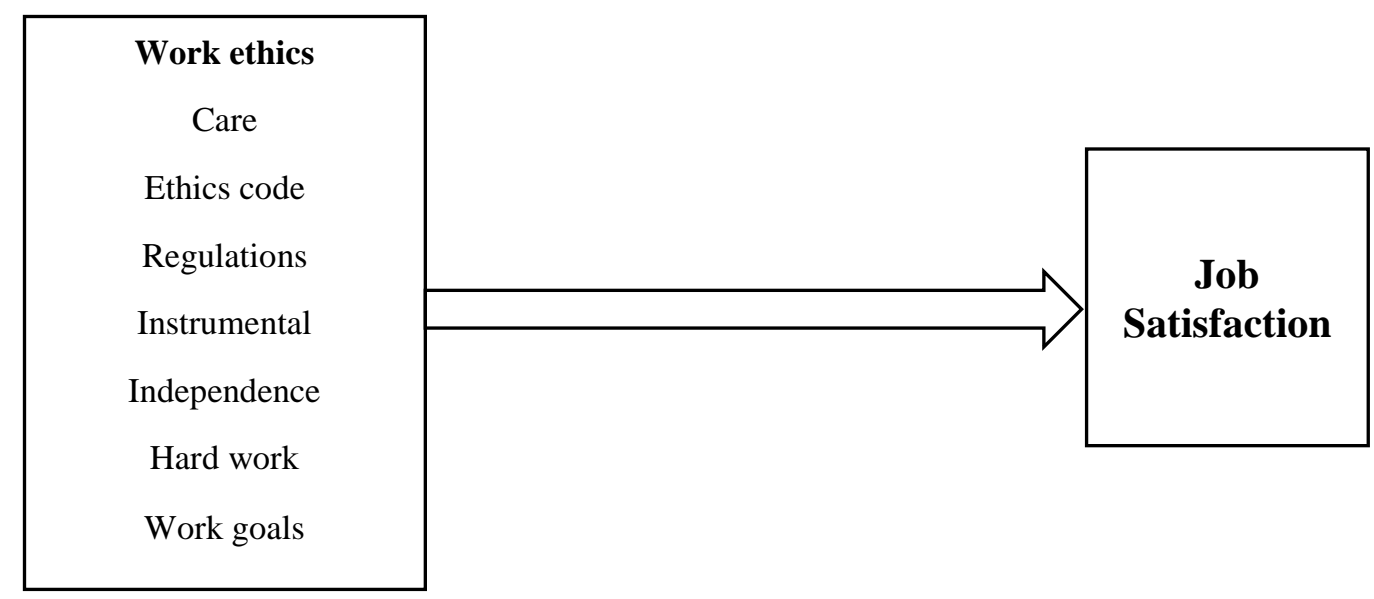

\section{Figure 1. Research Framework}

The current research framework is depicted in Figure.1.

\section{Methodology \\ Data collection and Measurement Scales}

This study decided to collect data from the front line managers working in three major commercial banks and each of them covering five branches in Amman Jordan. We distributed 160 survey questionnaire, out of which we are able to collect 93 responses. Four responses were found to have incomplete information and therefore they were excluded. It was not an easy task to reach out all the banking employees and thus the study sample was limited to 89 responses with the response rate of 55.62\%. All the banks were in the metropolitan areas of Amman. 76\% of the respondents were male and most of them were having a graduate degree. The mean age of the respondents was 33.8 (34) years ( $S D=6.79$ years). The mean experience level was 7.91 years (SD $=5.04$ years).

A self-administered survey questionnaire was delivered personally to the front line managers of Jordan banks with probability sampling technique. This particular respondents were selected as they are able to answer based on work ethics and job satisfaction. Furthermore, these particular employees have encountered a variety of ethical situation in their job. The survey was in English and Arabic in order to avoid any response bias. The survey included demographic information of the employees together with the constructs of work ethics and job satisfaction. Measures of work ethics and job satisfaction employed a 5 point Likert scale with (1) indicating less important and (5) indicating high important. Appendix provides the measurement scale considered for the study.

\section{Analysis}

The analysis involved descriptive statistics and bivariate correlations between each dimension of work ethics with the job satisfaction of the employees. Apart from that, an exploratory factor analysis (EFA) was first performed to determine the dimensionality and the factor structure of the variables. The measures for the work ethics was scored such that high score indicated high important. Thus, 
INTERNATIONAL JOURNAL OF ACADEMIC RESEARCH IN BUSINESS AND SOCIAL SCIENCES Vol. 8, No. 11, Nov, 2018, E-ISSN: 2222-6990 (C) 2018 HRMARS

positive correlation indicated support for the hypothesis: increase in work ethics will lead to increase job satisfaction of the employees.

\section{Results}

The mean, standard deviations and alpha coefficient of the constructs analyzed in this paper are reported in Table 2. The alpha coefficient for the constructs ranges from 0.68 to 0.89 . That is some of the variables was having less alpha coefficient than the criteria of 0.70 (Hair et al, 1998). In particular work ethics with instrument and independence have an alpha coefficient of 0.68 and 0.65 respectively.

As suggested by previous referees like (Tavakol \& Dennick, 2011; Vaske, Beaman, \& Sponarski, 2017) the item inter-correlation may be the reason for low reliability. It was found that after dropping the third item from the independence dimension of work ethics the alpha coefficient was improved from 0.65 to 0.72 . Also dropping the second item from the instrumental dimension of work ethics the alpha coefficient was improved from 0.68 to 0.74 . The cronbach's alpha statistic was consistent with the measures of other studies like (Khan, Abbas, Gul, \& Raja, 2015; Valentine, Fleischman, \& Godkin, $\underline{2015}$ ) of job satisfaction. When the level of job satisfaction in the workplace, the analysis follows the weighted average of the employee's response in each workplace (de Menezes, 2012).

Table 2. Descriptive Statistics and alpha coefficient

\begin{tabular}{|l|l|l|l|}
\hline Variable & Mean & $\begin{array}{l}\text { Standard } \\
\text { Deviation }\end{array}$ & Alpha coefficient \\
\hline Care & 3.97 & 1.43 & 0.79 \\
\hline Ethics code & 4.28 & 1.12 & 0.77 \\
\hline Regulations & 4.09 & 1.25 & 0.89 \\
\hline instrumental & 3.93 & 1.21 & $0.74^{*}$ \\
\hline independence & 4.73 & 1.16 & $0.72^{*}$ \\
\hline hard work & 3.95 & 1.01 & 0.81 \\
\hline work as goal & 4.42 & 1.05 & 0.82 \\
\hline Job satisfaction & 4.53 & 1.20 & 0.86 \\
\hline
\end{tabular}

* Revised alpha coefficient after removal of one item from the original measurement.

As shown in Table 3, all the correlations were significant at the 0.01 level. Thus the hypothesis of having significant correlations between dimensions of work ethics and job satisfaction was high. Amongst the dimensions of work ethics, instrumental was found to have a high significant correlation with the job satisfaction. Instrumental stands for selflessness among employees in the organization. Employees feel more satisfied when they are concern more with the needs and wishes of others than that of its own. The correlations between the work ethics of the front line employees and their job satisfaction are summarized in Table 3. 
Table 3. Bivariate correlations

\begin{tabular}{|l|l|}
\hline $\begin{array}{l}\text { Dimensions of work ethics correlated with job satisfaction } \\
\text { of the employees }\end{array}$ & Correlation \\
\hline Care & $0.488^{* *}$ \\
\hline Ethics code & $0.495^{* *}$ \\
\hline Regulations & $0.531^{* *}$ \\
\hline Instrumental & $0.535^{* *}$ \\
\hline Independence & $0.504^{* *}$ \\
\hline Hard work & $0.438^{* *}$ \\
\hline Work as goal & $0.481^{* *}$ \\
\hline
\end{tabular}

$\mathrm{N}=89 .{ }^{* *} \mathrm{p}<0.01 ;$ Two tailed

Generally, the findings of the study were consistent with the findings of previous literature studies on ethics. As compared to the findings of previous literature Koh and Elfred (2001), the current findings are stronger and possess a significant relationship between quality work ethics and job satisfaction. In contrast, Viswesvaran et al. (1998) found only one dimension of ethics having a positive correlation on job satisfaction.

Work ethics and job satisfaction were found to be separate factors as shown in Table.4. The factor loadings ranged from 0.502 to 0.92 and the three care items caring of people inside and outside the organization (0.55), good for all employees (0.593) and best for everyone in the organization (0.502) had low factor loadings. All the other measurements for the constructs were in the range of factor loading.

Table.4. Factor loadings

\begin{tabular}{|c|c|c|c|c|c|c|c|c|}
\hline 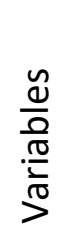 & $\frac{0}{\frac{1}{U}}$ & 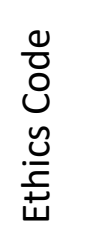 & 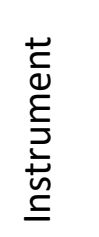 & 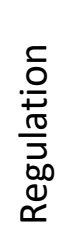 & 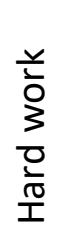 & $\begin{array}{l}\frac{n}{\pi} \\
0 \\
00 \\
\frac{1}{亡} \\
\vdots \\
3\end{array}$ & 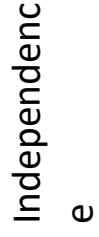 & 응 \\
\hline C1 & .550 & & & & & & & \\
\hline $\mathrm{C} 2$ & .593 & & & & & & & \\
\hline $\mathrm{C3}$ & .502 & & & & & & & \\
\hline EC1 & & .770 & & & & & & \\
\hline EC2 & & .773 & & & & & & \\
\hline EC3 & & .559 & & & & & & \\
\hline EC4 & & .816 & & & & & & \\
\hline IT1 & & & .647 & & & & & \\
\hline IT2 & & & .627 & & & & & \\
\hline
\end{tabular}


INTERNATIONAL JOURNAL OF ACADEMIC RESEARCH IN BUSINESS AND SOCIAL SCIENCES Vol. 8, No. 11, Nov, 2018, E-ISSN: 2222-6990 @ 2018 HRMARS

\begin{tabular}{|c|c|c|c|c|c|c|}
\hline IT3 & .621 & & & & & \\
\hline RE1 & & .809 & & & & \\
\hline RE2 & & .823 & & & & \\
\hline RE3 & & .815 & & & & \\
\hline RE4 & & .752 & & & & \\
\hline HW1 & & & .563 & & & \\
\hline HW2 & & & .727 & & & \\
\hline HW3 & & & .718 & & & \\
\hline CG1 & & & & .756 & & \\
\hline CG2 & & & & .819 & & \\
\hline CG3 & & & & .691 & & \\
\hline CG4 & & & & .649 & & \\
\hline IN1 & & & & & 0.92 & \\
\hline IN2 & & & & & 0.92 & \\
\hline IN3 & & & & & 0.85 & \\
\hline JS1 & & & & & & .692 \\
\hline JS2 & & & & & & .725 \\
\hline JS3 & & & & & & .693 \\
\hline JS4 & & & & & & .796 \\
\hline JS5 & & & & & & .793 \\
\hline
\end{tabular}

Note: Extraction Method: Principal Component Analysis; Rotation Method: Varimax with Kaiser Normalization; C - Care; EC - Ethical code; IT - Instrumental; RE - Regulations; HW - Hard work; CG - Career goals; IN - Independence; JS - Job satisfaction

\section{Regression analysis}

Hierarchal level regression analysis was conducted to test the hypothesis 1 . Hypothesis 1 suggested a positive influence of work ethics on job satisfaction. The result presented in Table.5 showed that factors of work ethics are positively associated with employee job satisfaction. Employee independence, hard work and work goal under work ethics was found to have high integration towards employee job satisfaction ( $p$ value $<0.05$ ). 
INTERNATIONAL JOURNAL OF ACADEMIC RESEARCH IN BUSINESS AND SOCIAL SCIENCES

Vol. 8, No. 11, Nov, 2018, E-ISSN: 2222-6990 @ 2018 HRMARS

Table 5. Regression analysis for work ethics and job satisfaction

\begin{tabular}{llll}
\hline Variables & $\beta$ & t-statistics & Significant Level \\
\hline Care & .162 & 1.438 & $0.094^{*}$ \\
Ethical Code & -.064 & -.749 & .450 \\
Regulations & -.010 & -.080 & .930 \\
Instrumental & .026 & .264 & .790 \\
Independence & .342 & 3.050 & $0.003^{* *}$ \\
Hard work & .257 & 3.053 & $0.003^{* *}$ \\
Work goal & .272 & 2.677 & $0.009^{* *}$ \\
\hline R square & 0.801 & & \\
F change & 46.664 & & \\
Durbin Watson & 1.952 & & \\
Significant level & 0.000 & & \\
\hline Note: Dependent & &
\end{tabular}

Note: Dependent variable: Job satisfaction

$\mathrm{N}=89 ;{ }^{*} \mathrm{p}<0.10 ; * * \mathrm{p}<0.01 ; * * * \mathrm{p}<0.001$

However, there was no evidence found for ethical code, regulations and instrumental influencing employee job satisfaction. The link between work ethics and employee job satisfaction was confirmed. It was worth noticing that Table 5 also shows weak interaction between care, ethical code, regulations and instrumentals with employee job satisfaction, which is the subject of investigation ( $p$ value $>0.05$ ). This may indicate that employees may experience unfit with the regulations they are bounded within the organization and that makes them uncomfortable. It is crucial for the organization to take proper care of their employees.

\section{Discussion}

The objective of the study was to explain how employee's perception towards ethical climate influence their job satisfaction level. In particular we focused on ethics at work to identify the underlying relationship with job satisfaction. More specifically, this study examined the hypothesis regarding the relationship between work ethics and job satisfaction. The result offered strong support for the hypothesis and found that work ethics is directly associated positively to job satisfaction. A linkage was established between caring climate with job satisfaction and the organization that emphasize work goals. The result indicated that work ethics dimensions like hard work $(\beta=0.34, p<0.001)$ and work goals $(\beta=0.257, p<0.001)$ have strong influence on job. This indicates that employees do care about their society welfare. This implication was related to Valentine and Fleischman (2008); Wood (1991) who mentioned that since the moral development of managers is known to influence employee's activities, organization should consider deeply various ethical issues while promoting or assigning tasks to the employees. They should also consider the extent to which the manager can react to the work based on ethical situations (Trevino, 1986). A strong culture can also enhance employee's ethical situation, however, if there is lack of individual ethics, organizational level policies might not be so effective to promote CSR. Lack of "individual 
INTERNATIONAL JOURNAL OF ACADEMIC RESEARCH IN BUSINESS AND SOCIAL SCIENCES

Vol. 8, No. 11, Nov, 2018, E-ISSN: 2222-6990 @ 2018 HRMARS

ethics" also one of the reason for insufficient satisfaction at their work (Kaptein, 2008). Therefore, companies should devise ethical training and moral development workshops that targets individual's ethical reasoning to promote more generalized ethical values with employees.

\section{Managerial Implications}

The main purpose of this study was to assess the role of work ethics on job satisfaction of employees. The result of this study revealed that banking employee's ethics influence their job satisfaction potentially. Furthermore, it was also found that commitment of the employees play a crucial role enhancing the relationship between ethics and satisfaction. Employees are willing to perform their task because they have positive feelings and emotions towards the company. However, it will be challenge to change work quality of an employee with the implementation of policies of what economists calls them a Pareto improvement.

Thus, favorable ethics is associated with job satisfaction with important implications. Work ethics and job satisfaction go hand in hand. Hard work and diligence are the examples of work ethics. Thus the managers must provide the moral benefit to work and ability to the employees. Ethics must be reliable, good social skills and positive initiatives. An employee having good work ethics is more eligible for selected positions, more responsibility and promotion. Whereas, the employee who fails to exhibit good work are not promoted or given greater responsibility. Although the job satisfaction of employees are recognized to be significant, studies regarding the ethics-job satisfaction relationship has received little attention. Few studies have attempted to examine the relationship between ethical climate and job performance (Aguinis and Glavas, 2012; Rupp and Mallory, 2015; Jones, 2010), however clear evidence of the relationship was limited.

This study helps the managers and individuals to understand theoretically and practically how the work ethics with reference to quality stimulate job satisfaction. Theoretically, many studies have explored the influence of organizational ethics on performance or satisfaction. Yet, seldom research has focused on work ethics of employees in the banking sector. Practically this study will help the organization to reduce their turnover and would support their employees to develop strong ethical behavior. It is suggested to the management leaders that producing a constructive job attitude and organizational outcomes can be fulfilled with work ethics. The result highlighted the importance of work ethics with emphasis laid on employees. The findings of having independency and work goals as an important factor of work ethics are very important for the banking professionals to keep their workforce satisfied. It is the responsibility of the employees and the organization to tackle ethical issues in the workplace.

\section{Conclusion}

Numerous studies found that work climate affect organizational performance and outcomes and satisfaction (Pritchard and Karasick, 1973; Wan and Chien, 2018). From the findings of this research it was found that ethical work climate have strong effect on job satisfaction of individuals. Thus this research adds to the work ethical climate by identifying important climate types. In this research we proposed ethical climate theory and it is our belief that organizational theory needs to be more explicit to control the ethical decision making. Work ethics is important for an individual wellbeing. As employees reciprocate their efforts, retention and engagement towards their work, they are 
highly satisfied in return. Ethical concerns by individuals in the organization have been the main focus of the study in recent years. Research examining individual concern of work ethics postulated to affect job satisfaction is almost nonexistent. Due to the globalization of businesses, there is an urgent need to perform an empirical investigation on work ethics towards job satisfaction of the individuals. This study investigated the correlation between work ethics dimensions and job satisfaction and the result obtained from bivariate correlations indicated a significant positive link between all the constructs. These findings imply that work ethics is one of the key attributes that can increase employee's job satisfaction together with other organizational outcomes. Most importantly, it is crucial for the managers to be aware that increasing employee's job satisfaction can lead to increased organizational commitment, lower labour turnover and improve productivity. This study used to care, ethical code, regulations, instrumental, independence, hard work and work goal as the dimensions of work ethics. However, the work ethics program can go beyond these components. The study found a significant contribution by work ethical dimensions like independence, hard work and work goals on job satisfaction. Furthermore, it was also revealed that it is a big challenge for the banks to maintain the satisfaction level of their employees.

\section{Emerging issues for future research on work ethics and job satisfaction}

Review of literature on ethics has noticed a surge in research on ethical behavior. However, very little research has focused on work ethics of employees as individual consequences. A key issue identified is the lack of theory about the nature of strong work ethics in the employees. Ethics is concerned with working goals and time utilization to fulfil the task wisely but a distinctive approach to this concern that matters is lacking. There is a little consensus on developing a theory of ethics. This study proposed that focusing on something like expectancy theory would provide a sensible rationale for the ethical practices. Expectancy theory configures depending on rewards and motivation indicating satisfaction can be considered with high performance. The alternative approach is to use the statistical method and to see what emerges from factor analysis. We would also care of corporate social responsibility associated with ethics and job satisfaction. Finally, there is a need to be cautious about the validity assumption while performing the data collection on the basis of different corporate departments. Finally, future research should be performed taking into consideration the consequences of quality and strong work ethics at international level. 
INTERNATIONAL JOURNAL OF ACADEMIC RESEARCH IN BUSINESS AND SOCIAL SCIENCES

Vol. 8, No. 11, Nov, 2018, E-ISSN: 2222-6990 @ 2018 HRMARS

\section{References}

[1] Abdi, M. F., Nor, S. F. D. W. M., \& Radzi, N. Z. M. (2014). The impact of Islamic work ethics on job performance and organizational commitment. Paper presented at the Proceedings of 5th Asia-Pacific Business Research Conference, Kuala Lumpur, Malaysia.

[2] Ali, A. J., \& Al-Kazemi, A. A. (2007). Islamic work ethic in Kuwait. Cross cultural management: An international Journal, 14(2), 93-104.

[3] Alsop, R., \& Heinsohn, N. (2005). Measuring empowerment in practice: structuring analysis and framing indicators. World, 1-123.

[4] Apasu, Y. (1986). Identifying the antecedents of salespersons intention to leave. Akron Business and Economic Review, 17(4), 85-97.

[5] Camp, S. D. (1994). Assessing the effects of organizational commitment and job satisfaction on turnover: An event history approach. The Prison Journal, 74(3), 279.

[6] de Menezes, L. M. (2012). Job satisfaction and quality management: an empirical analysis. International Journal of Operations \& Production Management, 32(3), 308-328.

[7] Doughty, H., \& Rinehart, J. W. (2004). Employee empowerment: Democracy or delusion. Innovation Journal, 9(1), 1-24.

[8] Elçi, M., \& Alpkan, L. (2009). The impact of perceived organizational ethical climate on work satisfaction. Journal of Business Ethics, 84(3), 297-311.

[9] Elkins, S. L. (2007). Job satisfaction and work ethic among workers in a Japanese manufacturing company located in the United States.

[10] Forte, C. S., \& Hansvick, C. L. (1999). Applicant age as a subjective employability factor: A study of workers over and under age fifty. Journal of Employment Counseling, 36(1), 24-34.

[11] Fu, W. (2014). The impact of emotional intelligence, organizational commitment, and job satisfaction on ethical behavior of Chinese employees. Journal of Business Ethics, 122(1), 137 144.

[12] Furnham, A. (1982). The Protestant work ethic and attitudes towards unemployment. Journal of Occupational and Organizational Psychology, 55(4), 277-285.

[13] Gawel, J. E. (1997). Herzberg's Theory of Motivation and Maslow's Hierarchy of Needs. ERIC/AE Digest: ERIC Clearinghouse on Assessment and Evaluation, 210 O'Boyle Hall, The Catholic University of America, Washington, DC 20064.

[14] Geren, B. (2011). The work ethic: is it universal? Journal of International Business \& Cultural Studies, 5, 1-8.

[15] Getahun, S., Sims, B., \& Hummer, D. (2008). Job Satisfaction and Organizational Commitment Among Probation and Parole Officers: A Case Study. Professional Issues in Criminal Justice (PICJ), 3(1), 1-16.

[16] Gill, A., Flaschner, A., \& Bhutani, S. (2010). The Impact of Transformational Leadership and Empowerment on Employee Job Stress. Business and Economics Journal, 1-11.

[17] Gui, L., Barriball, K. L., \& While, A. E. (2009). Job satisfaction of nurse teachers: A literature review. Part II: Effects and related factors. Nurse Education Today, 29(5), 477-487.

[18] Hair, J. F., Black, W. C., Babin, B. J., Anderson, R. E., \& Tatham, R. L. (1998). Multivariate data analysis (Vol. 5, No. 3, pp. 207-219). Upper Saddle River, NJ: Prentice hall.

[19] Hamilton-Attwell, A. (1998). Productivity and work ethics. Work study, 47(3), 79-86. 
INTERNATIONAL JOURNAL OF ACADEMIC RESEARCH IN BUSINESS AND SOCIAL SCIENCES Vol. 8, No. 11, Nov, 2018, E-ISSN: 2222-6990 @ 2018 HRMARS

[20] Hunjra, A. I., UI Haq, N., Akbar, S. W., \& Yousaf, M. (2011). Impact of Employee Empowerment on Job Satisfaction: An Empirical Analysis of Pakistani Service Industry. Interdisciplinary Journal of Contemporary Research in Business, 2(11), 680-685.

[21] Hussein, A. A., Wilkoff, B. L., Martin, D. O., Karim, S., Kanj, M., Callahan, T., . . Wazni, O. M. (2010). Initial experience with the Evolution mechanical dilator sheath for lead extraction: safety and efficacy. Heart Rhythm, 7(7), 870-873.

[22] Kaptein, M. (2008). Developing and testing a measure for the ethical culture of organizations: The corporate ethical virtues model. Journal of Organizational Behavior, 29(7), 923-947.

[23] Khan, K., Abbas, M., Gul, A., \& Raja, U. (2015). Organizational justice and job outcomes: Moderating role of Islamic work ethic. Journal of Business Ethics, 126(2), 235-246.

[24] Koh, H. C., \& El'Fred, H. (2001). The link between organizational ethics and job satisfaction: A study of managers in Singapore. Journal of Business Ethics, 29(4), 309-324.

[25] Komari, N., \& Djafar, F. (2013). Work Ethics, Work Satisfaction and Organizational Commitment at the Sharia Bank, Indonesia. International Business Research, 6(12), p107.

[26] Koonmee, K., Singhapakdi, A., Virakul, B., \& Lee, D.-J. (2010). Ethics institutionalization, quality of work life, and employee job-related outcomes: A survey of human resource managers in Thailand. Journal of business research, 63(1), 20-26.

[27] Kowal, J., \& Roztocki, N. (2015). Do organizational ethics improve IT job satisfaction in the Visegrád Group countries? Insights from Poland. Journal of Global Information Technology Management, 18(2), 127-145.

[28] Lincoln, N. D., Travers, C., Ackers, P., \& Wilkinson, A. (2002). The meaning of empowerment: the interdisciplinary etymology of a new management concept. International journal of management reviews, 4(3), 271-290.

[29] Mahembe, B., \& Chipunza, C. (2014). Job satisfaction and work ethics: a comparison between a South African and a Zimbabwean group. Interim: Interdisciplinary Journal, 13(2), 34-46.

[30] Maslow, Abraham H. (1970) Motivation and Personality, New York: Harper and Row

[31] Miller, M. J., Woehr, D. J., \& Hudspeth, N. (2002). The meaning and measurement of work ethic: Construction and initial validation of a multidimensional inventory. Journal of Vocational Behavior, 60(3), 451-489.

[32] Mobley, W. H. (1977). Intermediate linkages in the relationship between job satisfaction and employee turnover. Journal of applied psychology, 62(2), 237.

[33] Murtaza, G., Abbas, M., Raja, U., Roques, O., Khalid, A., \& Mushtaq, R. (2016a). Impact of Islamic work ethics on organizational citizenship behaviors and knowledge-sharing behaviors. Journal of Business Ethics, 133(2), 325-333.

[34] Murtaza, G., Abbas, M., Raja, U., Roques, O., Khalid, A., \& Mushtaq, R. (2016b). Impact of Islamic work ethics on organizational citizenship behaviors and knowledge-sharing behaviors. Journal of Business Ethics, 133(2), 325.

[35] Nykodym, N., Simonetti, J. L., Nielsen, W. R., \& Welling, B. (1994). Employee empowerment. Empowerment in Organizations, 2(3), 45-55.

[36] Okpara, J. O., \& Wynn, P. (2008). The impact of ethical climate on job satisfaction, and commitment in Nigeria: Implications for management development. Journal of Management Development, 27(9), 935-950. 
INTERNATIONAL JOURNAL OF ACADEMIC RESEARCH IN BUSINESS AND SOCIAL SCIENCES

Vol. 8, No. 11, Nov, 2018, E-ISSN: 2222-6990 @ 2018 HRMARS

[37] Petty, G. C., \& Hill, R. B. (2017). Work Ethic Characteristics: Perceived Work Ethics of Supervisors and Workers. Journal of STEM Teacher Education, 42(2), 2.

[38] Shacklock, A., Manning, M., \& Hort, L. (2011). Dimensions and types of ethical climate within public sector human resource management. Journal of New Business Ideas \& Trends, 9(1), 5166.

[39] Steinheider, T. W. B. (2006). "Shared Leadership: Can Empowerment Work in Police Organizations?". The Police Chief, 73, 48-55.

[40] Sun, Y., Gergen, E., Avila, M., \& Green, M. (2016). Leadership and job satisfaction: Implications for leaders of accountants. American Journal of Industrial and Business Management, 6(03), 268.

[41] Tavakol, M., \& Dennick, R. (2011). Making sense of Cronbach's alpha. International journal of medical education, 2, 53.

[42] Thau, S., Derfler-Rozin, R., Pitesa, M., Mitchell, M. S., \& Pillutla, M. M. (2015). Unethical for the sake of the group: Risk of social exclusion and pro-group unethical behavior. Journal of applied psychology, 100(1), 98.

[43] Turnipseed, D. L. (2002). Are good soldiers good?: Exploring the link between organization citizenship behavior and personal ethics. Journal of business research, 55(1), 1-15.

[44] Vacharakiat, M. (2008). The Relationships of Empowerment, Job Satisfaction, and Organizational Commitment among Filipino and American Registered Nurses Working in the USA. (Doctor of Philosophy in Nursing Dissertation), George Mason UniversityRetrieved from http://hdl.handle.net/1920/3363

[45] Valentine, S., \& Barnett, T. (2007a). Perceived organizational ethics and the ethical decisions of sales and marketing personnel. Journal of Personal Selling and Sales Management, 27(4), 373-388.

[46] Valentine, S., \& Fleischman, G. (2008). Ethics programs, perceived corporate social responsibility and job satisfaction. Journal of business ethics, 77(2), 159-172.

[47] Valentine, S., \& Barnett, T. (2007b). Perceived organizational ethics and the ethical decisions of sales and marketing personnel. Journal of Personal Selling \& Sales Management, 27(4), 373388.

[48] Valentine, S., Fleischman, G., \& Godkin, L. (2015). Rogues in the ranks of selling organizations: Using corporate ethics to manage workplace bullying and job satisfaction. Journal of Personal Selling \& Sales Management, 35(2), 143-163.

[49] Vaske, J. J., Beaman, J., \& Sponarski, C. C. (2017). Rethinking internal consistency in Cronbach's Alpha. Leisure Sciences, 39(2), 163-173.

[50] Victor, B., \& Cullen, J. B. (1988). The organizational bases of ethical work climates. Administrative Science Quarterly, 101-125.

[51] Victor, V. (1964). Work and motivation. John Willey \& Sons, New York.

[52] Vitell, S. J., \& Davis, D. L. (1990). The relationship between ethics and job satisfaction: An empirical investigation. Journal of Business Ethics, 9(6), 489-494.

[53] Valentine, S., \& Fleischman, G. (2008). Ethics programs, perceived corporate social responsibility and job satisfaction. Journal of business ethics, 77(2), 159-172.

[54] Victor, B., \& Cullen, J. B. (1988). The organizational bases of ethical work 
climates. Administrative science quarterly, 101-125.

[55] Viswesvaran, C., S. P. Deshpande and J. Joseph: 1998, 'Job Satisfaction as a Function of Top Management Support for Ethical Behavior: A Study of Indian Managers', Journal of Business Ethics 17, 365-371.

[56] Vitell, S. J., \& Davis, D. L. (1990). The relationship between ethics and job satisfaction: An empirical investigation. Journal of Business Ethics, 9(6), 489-494.

[57] Wan, T. T. H., \& Chien, S. F. (2018). Work Climate and Nurse Job Satisfaction of a Large Medical Center in Taiwan. J Hosp Health Care Admin: JHHA-114. DOI, 10.

\begin{tabular}{|c|c|}
\hline \multicolumn{2}{|c|}{ Appendix: Measurement items for the variables } \\
\hline Code & Measurement items \\
\hline Care1 & I take care of people inside and outside organization \\
\hline Care2 & $\begin{array}{l}\text { Good for all the employees in the organization is most important } \\
\text { concern }\end{array}$ \\
\hline Care3 & What is best for everyone is the major concern in this organization \\
\hline Ethic code1 & I make decision based on professional code of ethics \\
\hline Ethic code2 & $\begin{array}{l}\text { Employees in this organization are expected to strictly follow legal } \\
\text { standard }\end{array}$ \\
\hline Ethic code3 & $\begin{array}{l}\text { First consideration for the organization is to check whether employee } \\
\text { decision violates any law }\end{array}$ \\
\hline Ethic code4 & The law or ethical code of employee's profession is major concern \\
\hline Regulation1 & I obey rules set for employee working attitude \\
\hline Regulation2 & Every employee must stick to organization's rules and regulations \\
\hline Regulation3 & It is very important to follow organization's rules and procedures \\
\hline Regulation4 & Organizational policies are strictly obeyed in this organization \\
\hline Instrument1 & I am instrumental among people within the organization \\
\hline Instrument2 & $\begin{array}{l}\text { Employees protect other consideration rather than protecting their } \\
\text { own interest }\end{array}$ \\
\hline Instrument3 & Organization's interest is not hurt during the work consideration \\
\hline Instrument4 & Employees can do anything further to protect organization's interest \\
\hline Independent1 & I consider moral beliefs based on principles \\
\hline Independent2 & Employees have right to decide what is right and wrong \\
\hline Independent3 & Own personal and moral beliefs of employees are followed \\
\hline Hard work1 & I am always willing to work \\
\hline Hard work2 & I have positive attitude towards work \\
\hline Hard work3 & Working efficiently is my major concern \\
\hline
\end{tabular}


INTERNATIONAL JOURNAL OF ACADEMIC RESEARCH IN BUSINESS AND SOCIAL SCIENCES Vol. 8, No. 11, Nov, 2018, E-ISSN: 2222-6990 @ 2018 HRMARS

Work goal1 I am always self-esteemed with the work I do

Work goal2 Employees always attempts to improve their efficiency

Work goal3 Employees are always highly motivated

Work goal4 Employees set their tasks and attempts to fulfill them

JS1 I am satisfied with remuneration provided by the organization

JS2 I am satisfied with the career opportunity provided by the organization

JS3 I am satisfied working with co-workers in the organization

JS4 Supervisor is able to provide technical assistance and support to me

JS5 Job is interesting to me

JS6 I am satisfied with the training provided to me 